PROCEEDINGS OF THE WORLD CONFERENCE ON OZONE THERAPY IN MEDICINE, DENTISTRY AND VETERINARY. ANCONA (ITALY). SEPTEMBER 22nd - 23rd - 24th, 2017

\title{
Experimental protocol in veterinary on Borrelliosis (Lyme Disease) and Bartonellosis, concomitant cause of many serious pathologies treated with antibiotics, oxygen/ozone therapy and autologous stem cells [abstract]
}

\author{
Marco Polettini
}

Italy

\section{ABSTRACT}

\section{OPEN ACCESS}

\section{Citation}

Polettini M. Experimental protocol in veterinary on Borrelliosis (Lyme Disease) and Bartonellosis, concomitant cause of many serious pathologies treated with antibiotics, oxygen/ozone therapy and autologous stem cells [abstract]. Proceedings of The World Conference on Ozone Therapy in Medicine, Dentistry and Veterinary. Ancona (Italy). September 22nd - 23rd - 24th , 2017. J Ozone Ther. 2019;3(4):48. doi: 10.7203/ jo3t.3.4.2019.15529

Academic Editor Jose Baeza-Noci,

School of Medicine, Valencia University, SPAIN

\section{Editor}

World Federation of Ozone Therapy, Bolgna, ITALY

\section{Received}

June 17, 2019

\section{Accepted}

December 08, 2019

Published

December 30, 2019

\section{Intellectual Property}

Marco Polettini.

This is an open access article distributed under the terms of the Creative Commons Attribution License (CC BY 4.0), which permits unrestricted use, distribution, and reproduction in any medium, provided the original author and source are credited.

\section{Author Information}

marcopolettini@libero.it
Introduction. Many recent publications have spoken about the relations between Borreliosis and Bartonellosis, and pathologies such as Parkinson's Multiple Sclerosis, LAS, cluster headache, depression, autism, epilepsy, cancer, etc...

The aim is to see if subjects with these two infections, pathologies considered incurable, respond positively to a protocol that includes antibiotics, oxygen/ozone therapy and autologous stem cells.

Results. The results of this protocol on serious pathologies considered incurable in veterinary and overlapping human pathologies, are giving good outcomes.

Discussion. The difficult to diagnose Borrelliosis and Bartonellosis in the Lab and variability of the clinical symptoms cause difficulty to both human and veterinary doctors. Even when these pathologies are confirmed by analyses they are treated with a short antibiotic cycle. Because bacteria have systems to overcome antibiotics the pathologies become chronic leading to sub-clinical meningitis that also blocks the correct functioning of the autonomous nervous system that regulates every physiological process. Serious pathologies appear even years after bacterial contamination and mankind's increasing longevity together with these bacterias' tropism can cause or has already caused a pandemic.

Conclusions. Alternating or combining therapies using various antibiotics, together with the antibacterial and catalytic effect of the oxygen/ozone therapy in the antibiotics and stem cells and the immunomodulation and neurotrophic effect of the Blood Stem Cells can indirectly resolve pathologies considered incurable up to now. 